Kingston : Forest Department, 1949), Mr. E. W. March, the conservator, states that the afforestation financed by the Colonial Development and Welfare Funds continued to be the main object of the Department during the year. At the same time, the wider outlook and activity of a forest department are now being gradually adopted. The general forest policy for Jamaica is outlined and shows that the outlook of the Government itself is wider than in the past. Three points are laid down: (1) the establishment of adequate areas of forest reserves under public ownership and their management on the basis of conservation and development for multiple use (protective, productive, scenic, recreational and wildlife) ; (2) the encouragement of sound forest management on private lands; (3) the development of the use of native timbers and other forest products to provide the highest possible proportion of the requirements of the Island. Under forest offences, fire is one of the chief causes; but on this subject the report is rather vague. The writer says: "The menace of bush fires caused by cultivators burning as an aid to clearing continues to be one of the main causes of soil deterioration in the Island and one of the biggest handicaps facing the soil conservationist and agriculturist". If by this, as one would suppose is the case, the conservator is alluding to shifting cúltivation, it surely merits a more detailed consideration in a forestry report than these few lines.

\section{Ellipsoidal Waves, Gravitation and Magnetism}

ABovt five years ago (Nature, 155,$4 ; 1945$ ) an account was given of $H$. Varcollier's theory of ellipsoidal waves. In a recent paper (Arch. Sci. Phys. et Nat., 2, Fas. 1 and 2 ; 1949) he develops this further into a form of unified field theory, with special emphasis on the connexion between gravitation and magnetism. It is claimed (pp. 82-88) that this theory leads directly to the Prunier-Blackett formula connecting the magnetic moment of massive rotating bodies with their angular momentum. On pp. 81-82 is suggested an experimental test of the theory which might be performed with two magnets in a laboratory.

\section{University of Sheffield}

WORK is to begin shortly on a great enlargement of the buildings of the Engineering Departments of the University of Sheffield, one of the most important items in the University's development programme and one which most closely touches local industries. The new building will join on to the existing buildings at St. George's Square. It will provide completely new accommodation for the Department of Civil Engineering, will treble the space available for the Department of Mechanical Engineering and by the consequent rearrangements will make room for a muchneeded expansion of the Department of Electrical Engineering. The Departments will then be able to accept each year some three times as many students as can be admitted now, there will be more adequate provision for research and the new Postgraduate School of Applied Mechanics will be worthily housed. The total cost of erection and equipment of the new Engineering building is estimated at $£ 350,000$. The University Grants Committee has made a grant to the University of $£ 250,000$ towards the cost, and the balance will have to be met from the University's Development Fund.

\section{Scottish Branch of Aslib}

A Conference of the Scottish Branch of Aslib will be held at the Mitchell Library, Glasgow, on April 14 ; Dr. D. G. Brown, chairman of the Branch, will preside. The opening address will be delivered by the Right Hon. Thomas Johnstone; after which there will be papers by James Fergusson, keeper of the Records of Scotland; Sir James French, chairman of the Royal Technical College, Glasgow, on "Books in Industry"; W. A. Beck, superintendent for Scotland of H.M. Stationery Office, on "The Range of Government Publications" ; and S. Weinberg, Research Department, G. and J. Weir, Ltd., on "The Attitude of the Research Worker to Terhnical Information". Further particulars can be obtained from the Honorary Secretary, Scottish Branch of Aslib, at the Institute of Seaweed Research, Inveresk Gate, Musselburgh, Midlothian.

\section{Announcements}

ThE Council of the Institute of Welding has awarded the Sir William J. Larke Medal, for the best paper read to the Institute during the year, to $\mathbf{M r}$. R. G. Braithwaite, welding consultant to Braithwaite and Co. (Structural), Ltd., for a paper on the control of distortion in arc welding.

The thirty-eighth Progress Medal of the Royal Photographic Society has been awarded to Prof. John Eggert, of the Swiss Federal Institute of Technology, Zurich, in recognition of his classical work in latent image theory, particularly on the quantum efficiency carried out with Noddack; for his work on the effect of X-rays on photographic emulsion; and in evolving methods of standardization of photographic speed and graininess. The Medal, which is the highest honour the Society can bestow, is awarded annually in recognition of any invention, research, publication or exhibition which shall have resulted in any important advance in the science, art or practice of photography.

M. CAquot (France) has been elected president of the Organisation for Standardization (ISO) in succession to Mr. Howard Coonley (United States). M. Caquot has had a distinguished career as a civil engineer. Membership of the Organisation is confined to representatives of the national standards bodies throughout the world.

The London Section of the Oil and Colour Chemists' Association is organising a technical trade exhibition of raw materials and equipment used in the paint, varnish and printing-ink industries, to be held at the Borough Polytechnic, Borough Road, London, S.E.1, during April 13-14 (3-9 p.m. each day).

AT the annual general meeting of the Chemical Society held in Edinburgh on March 29, the following were elected officers : President, Prof. E. K. Rideal ; Vice-President, Prof. R. P. Linstead; New Members of Council, Dr. J. S. Anderson (Harwell), Prof. L. Hunter (Leicester), Prof. F. E. King (Nottingham), Dr. L. N. Owen (London, Imperial College).

Erratum. In the communication entitled "Oxidation of Catechol by Tea-Oxidase" (Nature, January 7 , p. 32), the description of curve II in Fig. 1 is incorrect; the system under examination contained 40 mgm. washed enzyme $+11 \mathrm{mgm}$. catechol + $3 \mathrm{mgm}$. ascorbic acid at $p \mathrm{H} \mathbf{5 \cdot 6}$. 